\title{
Assessment and Modeling of Bond Strength of Corroded Reinforcement in Concrete Structures
}

\author{
V.P. Yartsev*, A.N. Nikolyukin, T.M. Pluzhnikova \\ Tambov State Technical University; \\ 112D, Michurinskaya St., Tambov, 392032, Russia \\ * Corresponding author. Tel.: +7 47526303 80. E-mail: kzis@nnn.tstu.ru
}

\begin{abstract}
One of the most serious causes of the loss of load-bearing capacity of reinforced concrete structures is bond failure between reinforcement and concrete as a result of structural degradation (corrosion) of metal parts. As a consequence, there is a need to study the behavior of corroded reinforcement in reinforced concrete parts.

The purpose of this study is to develop an analytical description of the ultimate bond strength of a reinforcing bar in reinforced concrete structures subject to different levels of corrosion. The modeling technique considered in this research is based on artificial neural networks.
\end{abstract}

\section{Keywords}

Analytical model; bond strength; corrosion; experimental database; reinforcement; concrete; artificial neural networks.

(c) V.P. Yartsev, A.N. Nikolyukin, T.M. Pluzhnikova, 2018

\section{Introduction}

One of the most important problems in the modern practice of design and operation of buildings is to predict the life of structures made of modern (new) materials exposed to various external factors. However, some factors can have a negative impact on many materials. Bonds between reinforcement and concrete can be damaged due to the negative impact of external factors. Extensive experimental studies concerning the changes in the bond strength in reinforced concrete under the influence of individual factors have been described in the literature so far. However, a model that takes into account the influence of individual factors or their complex impact on any material has not been developed yet.

Factors influencing the bond strength between reinforcement and concrete include the type of the reinforcing bar, the concentration of corrosive substances, the concrete quality, thickness, etc.

When considering the theory of reinforced concrete structures, it is noteworthy that reinforced concrete ceases to work as a single composite when the maximum stress in the reinforcement is reached.
However, the structure during operation is exposed to various impacts that lead to the formation of cracks around the bar, which weakens the bond between the reinforcement and concrete. In addition, the influence of some factors (aggressive media, corrosion of the material, etc.) leads to a decrease in the strength characteristics of the composite materials and the formation of normal cracks in the structure. Under load, an increase in the crack opening width, resulting in additional zones of stress concentration, is observed.

Industrial buildings are most exposed to the negative impact of external factors, as they are influenced by aggressive environments and loads of various kinds, leading to the accumulation of defects in the design. Studies have shown that some effects can have a positive influence on the design. For example, a low level of corrosion of the metal bar leads to a slight increase in the bond strength between the reinforcement and concrete, resulting from the increased pressure on the concrete mass in the stage without cracks. However, once the crack occurs, the bond strength begins to decrease as the corrosion level increases.

In most studies related to durability, the focus is on protecting structural reinforced concrete parts from 
the effects of degrading factors, or restoring the structure. Studies on experimental monitoring of the behavior of the reinforcement bond mainly lack analytical modeling. However, in the literature there are some scientific works in which the influence of various factors on the bond strength was estimated and modeled using theoretical or finite elements [1-5]. Having analyzed the available literature, it can be noted that a practical and general model for the estimation of the bond strength has not been developed yet.

In recent years, soft computing technologies have been successful implemented to predict some key properties of concrete and reinforced concrete [6-8].

For example, Mermerdas [9] used programming of gene expression to develop a setting shrinkage model. In Duan's research [10], the applicability of artificial neural networks (NN) for predicting the compressive strength of the concrete used was presented. About 150 experimental data obtained from public sources were used to build the NN model. The results of the study of reinforced concrete structures using soft computing have been described in the literature. This method made it possible to study the corrosion density of reinforced concrete slab [13], the bond of concrete floor layers [11] and the load-bearing capacity of the anchor in the concrete block [14]. Regarding the application of soft computing for the calculation of the concrete surface bonding, the information provided in the literature is not sufficient. These studies were mainly focused on the prediction of the bond strength between steel bars and concrete [16, 17]. For example, Dahou [16] used an artificial neural network to model the relations between conventional ribbed steel bars and concrete. The NN models were implemented using a database of 112 results of experimental tests on concrete bond to reinforcement by the method of pullout testing.

Artificial neural networks and fuzzy logic were used by Golafshani [17] to study bond strength between steel bars and concrete. When constructing the NN, the experimental data of 180 different test samples was used. However, according to many authors, no scientific approach to using soft computing to predict the bond strength between corroded steel bars and concrete has been developed yet.

This study presents analytical models created on the basis of artificial neural networks (NN) to predict the tensile strength of concrete bond $\tau_{\mathrm{b}}$. To do this, pullout tests were carried out on the concrete cubes. The data obtained experimentally were used for training and testing of the proposed models. As a result, the statistical efficiency of the NN-based model to predict bond strength between the corroded reinforcement and concrete was evaluated and compared.

\section{Literature Review}

It was the German researchers Zaliger $\mathrm{R}$. and Bach $G$. who estimated the bond strength between concrete and reinforcement for the first time.

Initially, the experiments were aimed at testing the strength of reinforcement anchoring in concrete for the end reinforcements of bends, loops and hooks. However, this method made it possible to investigate anchoring of modern profiles with high-strength concretes [18]. At the same time, bonding was considered as a power characteristic, depending on many factors, the specific value of which was estimated by scientists ambiguously. Nevertheless, in the middle of the twentieth century, Ya.V. Stolyarov believed that bonding directly depends on the bond capacity of the cement gel and the friction that occurs between the materials under the action of radial pressure from concrete shrinkage.

In his studies, Ya.V. Stolyarov identified two groups of factors. The first group refers to a number of factors that affect the slip resistance of reinforcement in concrete [19]. These include the bonding of the projections with concrete, the shrinkage friction and bonding of reinforcement with concrete. The second group quantifies the factors of the first group without affecting the bond. It includes the class and age of concrete.

The stress-strain state in stress redistribution zones is very ambiguous and depends on all factors in the aggregate. However, D.A. Abrams in his work found that the stress-strain state (SSS) in the areas of shear stresses of the bond varies significantly under load.

Since the bond is affected by a huge number of factors, it became necessary to apply a phenomenological approach of mathematical analysis of experimental data on the basis of simplifying assumptions.

T. Garay, M.Z.P. Brice and A. Bichara found out that it was quite time-consuming to experimentally determine the value of normal stresses in the reinforcement $\sigma_{\mathrm{s}}$ in the redistribution area by measuring it in the contact zone [20]. As a result, the application of this characteristic to assess the bond strength $\tau_{\mathrm{b}}$ in the contact zone was limited.

On the basis of Abrams's research, in 1913, Ya.V. Stolyarov constructed a curve for the dependence of the bond stress $\tau_{b}$ on "strain slip" for a bar with a variable profile. However, in 1941, S.E. Freifeld spoke about the relation between the bond stress and mutual displacements of the reinforcement relative to the concrete for the first time. 
M.M. Kholmansky conducted tests and found the value of the mutual displacement of the reinforcement relative to concrete [21]. The studies were observations of reinforcement displacements relative to concrete during pre-stressing and pulling out the reinforcement from the end-supported prisms.

In order to reduce the calculation complexity and improve the accuracy of the results obtained in the study of bond at certain permissible limits of displacements in the joint, the most commonly used elastic-plastic bond law (Prandtl diagram). The Prandtl diagram is close to the normal bond law, which was experimentally established by M.M. Kholmyansky and his students (Fig. 1) [22]. To simplify the calculations, equation 1 was derived, which determined the average stress values over the entire anchorage zone of the sample.

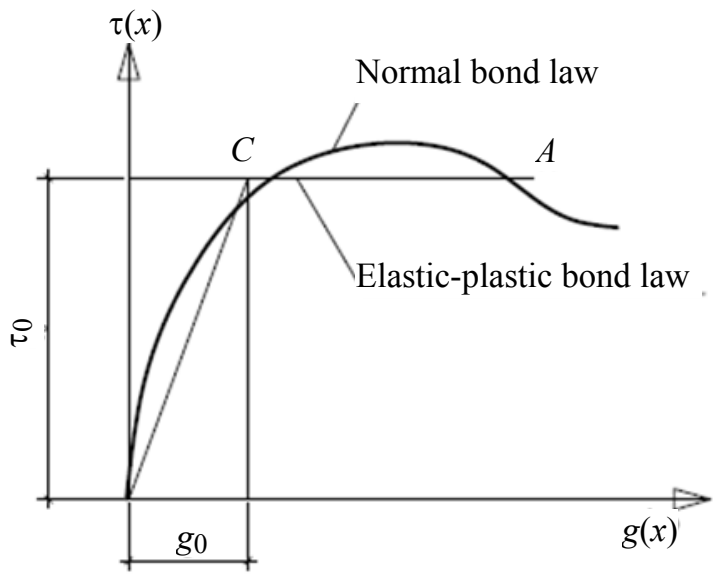

Fig. 1. “ $\tau-g$ ” diagram: elastic-plastic and normal laws of bond

$$
\tau_{\mathrm{b}}=\frac{N_{\max }}{A l}
$$

where $N_{\max }$ is ultimate load $(N)$ in the pullout test $(\mathrm{kN})$; $A$ is reinforcement perimeter $(A=\pi d$, where $d$ is bar diameter $(\mathrm{mm})), l$ is depth of setting $(\mathrm{m})$.

The reason for an increased interest in the issue of bond in the USSR in 1950-1960 was the active introduction of pre-stressed reinforced structures. As a result, fundamental experimental and theoretical studies on the problem of bond were conducted under the guidance of M.M. Kholmyansky [23-31] and A.A. Oatul [32-40].

However, M.M. Kholmyansky and H. Trost had significant disagreements in the interpretation of the law of bond between reinforcement and concrete.

It was found that the interaction of the bar strands concrete under the load of the reinforcement is characterized by screw motion in the concrete. In the preliminary reduction stage, considerable displacements up to $1 \mathrm{~mm}$ were observed. In this case, the displacement $g$ is a conditional characteristic with respect to the bond under the load of profiled reinforcing bars.

Longitudinal forces, arising in the strands, press its protrusions to the "concrete nut" (Fig. 2). In this case, there is a correlation between friction from the transverse pressure of the bar on concrete in the contact zone and the periodic profile of the reinforcement.

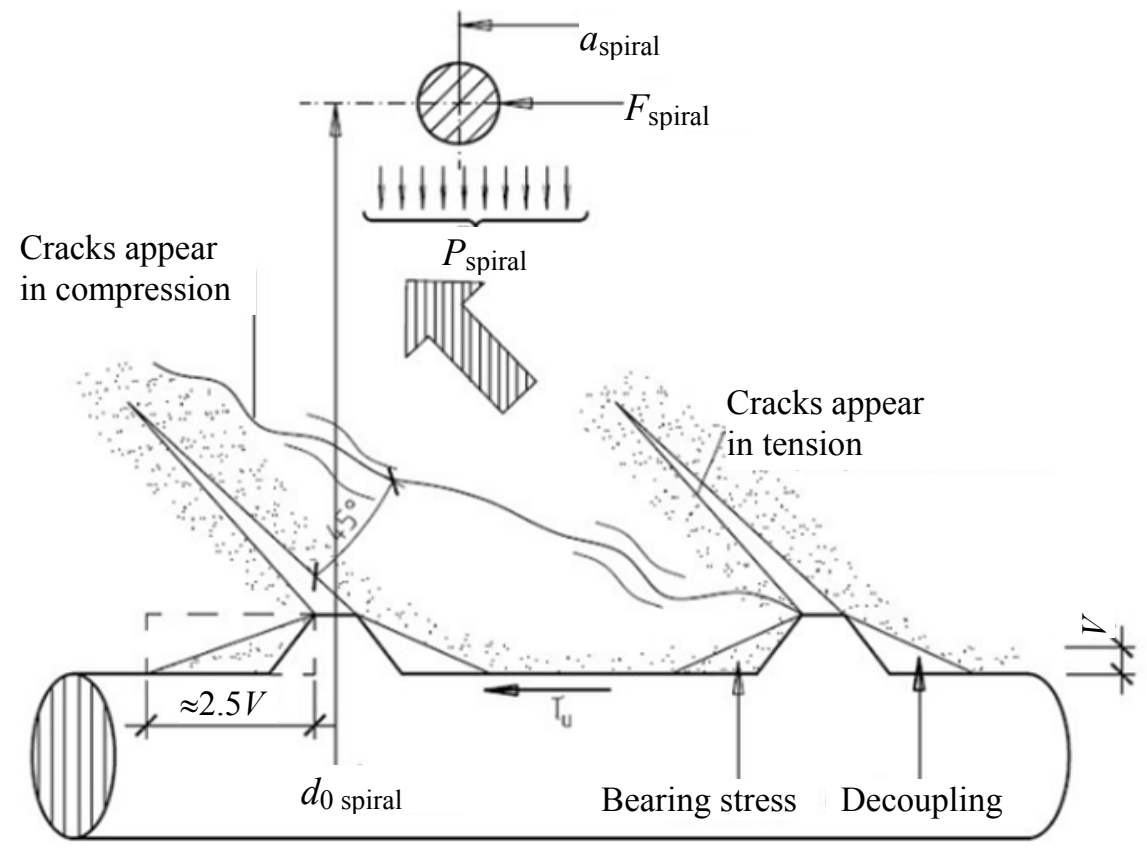

Fig. 2. Destruction of concrete console 
The phenomenological method in determining $\tau_{\mathrm{b}}$ has a number of shortcomings:

- constrained deformations are not taken into account;

- it is impossible to determine the SSS at contact zones in the development of cracking and plastic deformations;

- deformation of the concrete shell along the entire length of the anchoring is possible.

The above-mentioned shortcomings were eliminated with the development of computational models, the principle of which was based on the theory of creep and elasticity theory.

The application of numerical calculation methods and a computer in conjunction with the bond simulation allowed obtaining reliable and detailed results without carrying out laborious experiments.

To study reinforcement bond with concrete in a beam under pure bending conditions, A.S. Scordelis and D. Ngo used the finite element method for the first time. It was found that the interaction of reinforcement with concrete depends on the contact of the final element, which determines the physical and mechanical properties. In addition, there was a correlation between the development of cracks, both normal and inclined to the longitudinal axis of the beam, and the value of the external load. This method has been widely used both abroad and in the USSR.

Another method based on finding the SSS of concrete in the area adjacent to the periodic profile reinforcement was proposed by N.S. Karpenko and G.N. Sudakov. For calculation, a concrete area of cylindrical shape was used in the contact zone with the reinforcement. The interaction of the computational domain with external factors was elastic bonds. To determine the nature of the combined action of the reinforcement and concrete, conditions were set on the inner surface of the design cylinder. When solving this problem, it was expedient to use a variationaldifference method, which allowed predicting the development of cracks and determining the concrete SSS during cracking.

Since the unified theory of bonding did not exist for a long time, P.P. Nazarenko proposed a "generalized law of friction of steel reinforcement with concrete".

Currently, the problem associated with the bond between the reinforcement and concrete, is quite relevant. This topic is of fundamental importance for the design of reinforced concrete structures and the improvement of calculation techniques. One possible way to solve this problem is to use soft computing.

\section{Effect of concrete strength on bond}

As it was noted by M.M. Kholmyansky, the value of the bearing stress when pulling out the anchors reached 5-20 times of the cubic strength. In turn, N.M. Mulin determined the value of the ultimate stress under the reinforcement projections, which amounted to 15-20 $R_{\mathrm{b}}$. However, the role of strength in the reinforcement bond has not been studied completely [12].

Based on the conducted experiments on pulling seven-wire strands from prisms, A.I. Semenov noted a significant increase in the maximum pulling load $P_{\max }$ in the process of increasing the strength from 12.5 to $25 \mathrm{MPa}$. However, if the strength increased from 25 to $45 \mathrm{MPa}$, then the increase in $P_{\max }$ was observed only for samples whose length of stress transfer section is $l_{p}=20 d$, where $\mathrm{d}$ is the nominal diameter of the bar, and if $l_{p}=(40-60) d$, the bar breaks. In addition, Yu.M. Redko and E.F. Panyukov determined that the anchoring conditions did not depend on the change in the concrete strength from 25 to $70 \mathrm{MPa}$ during the prestressing of the cable rope.

In their studies, Al Khalili, E.W. Bennet, J.A. Uijl established a directly proportional dependence of the bond strength on the concrete strength.

N. Trost determined the dependence of the reinforcement strength of the periodic profile on the concrete strength. The bar bond is proportional to the square root of the concrete strength.

The concrete strength affects the length of the stress transfer section and the mechanism of bonding in general, if its value does not exceed $30 \mathrm{MPa}$. If the concrete strength is more than $30 \mathrm{MPa}$, it does not affect the bond. In this case, the bond depends on the rigidity of the concrete cage and the intensity of the indirect reinforcement.

\section{Experimental data}

To carry out theoretical studies, experimental results were used when testing 250 samples. The examples are presented in Table 1. The ultimate bond strength between reinforcement and concrete was calculated by equation (1).

Many researchers believed that the stress distribution in the early stages of pulling out is uneven, but it becomes almost homogeneous in the limiting state. Therefore, the expression of the limiting adhesion force in equation 1 can be considered as the average bonding stress between concrete and reinforcement. This method of calculating the value $\tau_{\mathrm{b}}$ (equation (1)) provides a practical approach for determining the bond strength between concrete and reinforcement, but it 
Examples of experimental data used to construct a model

Table 1

\begin{tabular}{|c|c|c|c|c|c|c|c|}
\hline No. & $\begin{array}{l}\text { Cube compressive } \\
\text { strength } \\
\text { of concrete } R_{\mathrm{b}}, \mathrm{MPa}\end{array}$ & $\begin{array}{l}\text { Surface dimensions } \\
\text { of a concrete } \\
\text { sample, } \mathrm{mm}\end{array}$ & $\begin{array}{l}\text { Rebar } \\
\text { profile }\end{array}$ & $\begin{array}{c}\text { Diameter } \\
\text { of the bar, } \mathrm{mm}\end{array}$ & $\begin{array}{l}\text { Depth of bar } \\
\text { anchoring, mm }\end{array}$ & $\begin{array}{l}\text { Corrosion } \\
\text { level, } \%\end{array}$ & $\begin{array}{c}\text { Maximum } \\
\text { tangential stress, } \\
\mathrm{MPa}\end{array}$ \\
\hline 1 & 23 & 45 & 2 & 14 & 50 & 3.81 & 1.3 \\
\hline 2 & 51 & 15 & 2 & 14 & 50 & 0 & 19.6 \\
\hline 3 & 51 & 15 & 2 & 14 & 50 & 0 & 14.3 \\
\hline 4 & 51 & 15 & 2 & 14 & 50 & 0 & 20 \\
\hline 5 & 51 & 30 & 2 & 14 & 50 & 0 & 20.9 \\
\hline 6 & 51 & 30 & 2 & 14 & 50 & 0 & 21.7 \\
\hline 7 & 51 & 30 & 2 & 14 & 50 & 0 & 21 \\
\hline 8 & 51 & 45 & 2 & 14 & 50 & 0 & 21.2 \\
\hline 9 & 51 & 45 & 2 & 14 & 50 & 0 & 27.4 \\
\hline 10 & 51 & 45 & 2 & 14 & 50 & 0 & 27.8 \\
\hline 11 & 51 & 15 & 2 & 14 & 50 & 1.33 & 18.5 \\
\hline 12 & 51 & 15 & 2 & 14 & 50 & 7.48 & 3.5 \\
\hline 13 & 51 & 15 & 2 & 14 & 50 & 4.47 & 6.3 \\
\hline 14 & 51 & 15 & 2 & 14 & 50 & 0.77 & 22.3 \\
\hline 15 & 51 & 15 & 2 & 14 & 50 & 0.8 & 22.4 \\
\hline 16 & 51 & 15 & 2 & 14 & 50 & 0.9 & 21.7 \\
\hline 17 & 51 & 15 & 2 & 14 & 50 & 0.94 & 21.5 \\
\hline 18 & 22.13 & 44 & 1 & 12 & 80 & 0.27 & 2.65 \\
\hline 19 & 22.13 & 44 & 1 & 12 & 80 & 0.29 & 3.23 \\
\hline 20 & 22.13 & 44 & 1 & 12 & 80 & 0.92 & 5.79 \\
\hline 21 & 22.13 & 44 & 1 & 12 & 80 & 1.13 & 5.84 \\
\hline 22 & 22.13 & 44 & 1 & 12 & 80 & 0.78 & 7.41 \\
\hline 23 & 22.13 & 44 & 1 & 12 & 80 & 1.47 & 8.63 \\
\hline 24 & 22.13 & 44 & 1 & 12 & 80 & 1.85 & 7.3 \\
\hline 25 & 22.13 & 44 & 1 & 12 & 80 & 1.5 & 7.96 \\
\hline 26 & 22.13 & 44 & 1 & 12 & 80 & 1.99 & 9.29 \\
\hline 27 & 22.13 & 44 & 1 & 12 & 80 & 1.04 & 10.26 \\
\hline 28 & 22.13 & 44 & 1 & 12 & 80 & 2.75 & 5.97 \\
\hline 231 & 29 & 145 & 2 & 25 & 160 & 1.31 & 10.59 \\
\hline 232 & 29 & 145 & 2 & 25 & 160 & 2.22 & 5.61 \\
\hline 233 & 29 & 145 & 2 & 25 & 160 & 3.16 & 12.72 \\
\hline 234 & 29 & 145 & 2 & 25 & 160 & 0.79 & 9.06 \\
\hline 235 & 23 & 15 & 2 & 14 & 50 & 4.32 & 12 \\
\hline 236 & 23 & 15 & 2 & 14 & 50 & 4.33 & 12 \\
\hline 237 & 28 & 79.4 & 2 & 19 & 177.8 & 0 & 6.32 \\
\hline 238 & 28 & 79.4 & 2 & 19 & 178.8 & 0 & 5.79 \\
\hline 239 & 28 & 79.4 & 2 & 19 & 179.8 & 0.72 & 7.67 \\
\hline 240 & 28 & 79.4 & 2 & 19 & 180.8 & 0.72 & 7.13 \\
\hline 241 & 28 & 79.4 & 2 & 19 & 181.8 & 0.98 & 8.41 \\
\hline 242 & 28 & 79.4 & 2 & 19 & 182.8 & 1.23 & 4.91 \\
\hline 243 & 28 & 79.4 & 2 & 19 & 183.8 & 1.44 & 3.1 \\
\hline 244 & 28 & 79.4 & 2 & 19 & 184.8 & 1.7 & 3.79 \\
\hline 245 & 28 & 79.4 & 2 & 19 & 185.8 & 2.21 & 3.7 \\
\hline 246 & 28 & 79.4 & 2 & 19 & 186.8 & 2.88 & 2.09 \\
\hline 247 & 28 & 79.4 & 2 & 19 & 187.8 & 5.19 & 1.41 \\
\hline 248 & 27.2 & 40 & 2 & 22.3 & 500 & 0 & 6.96 \\
\hline 249 & 28.4 & 40 & 2 & 22.3 & 500 & 2.5 & 2.89 \\
\hline 250 & 24.4 & 40 & 2 & 22.3 & 500 & 11.9 & 2.27 \\
\hline 251 & 27.7 & 40 & 2 & 22.3 & 500 & 28.9 & 2.38 \\
\hline
\end{tabular}


does not reflect the actual state of the structure, since it does not take into account factors such as the formation of stress cracks, local collapse, support reactions, etc.

Six critical parameters were used in the model. The input variables were compression strength, concrete sample size, reinforcing bar profile, reinforcement diameter, embedment depth, corrosion level, maximum bond strength.

These prognostic parameters were used to develop the model as an estimate of the ultimate bond strength between corroded reinforcement and concrete. The ranges of each variable are presented in [41-49]. For example, the steel bar diameter, the embedment depth, the dimensions of the upper face of the concrete cube, and the level of corrosion were in the range $12-25 \mathrm{~mm}, 80-500 \mathrm{~mm}, 40-147.5 \mathrm{~mm}$ and $0-80 \%$, respectively. The tests used A240-A400 valves. The size of the samples was $150 \times 150 \times 150 \mathrm{~mm}$. After the effect of various factors on the specimens, the bond strength between the core and concrete was determined by testing the pulling cubes (Fig.3).

In all the studies used in the preparation of the database, corrosion induction was achieved with the help of similar electrochemical systems. A schematic depiction of a typical accelerated corrosion plant is shown in Fig. 4. To induce different levels of corrosion on the reinforcement, potentiometers were used to control the intensity of the current. The current in this case served as a catalyst, namely, it accelerated the corrosion process of the reinforcing bar. All systems had cathode (counterelectrode) and anode (reinforcing) connections for the corrosion process. All samples were immersed in $\mathrm{NaCl}$ solution. To avoid corrosion of the open bar during the test, a coating was used for the reinforcing bar and the upper surface of the concrete.

Electrochemical systems sometimes consist of different components. In this case, the degree of corrosion is measured as the weight loss of reinforcing bar weights. In all studies, the calculated (theoretical) weight loss of the reinforcing bars due to corrosion was evaluated using the Faraday law. Then the actual (experimental) level of corrosion or the percentage loss of sample weight was calculated.

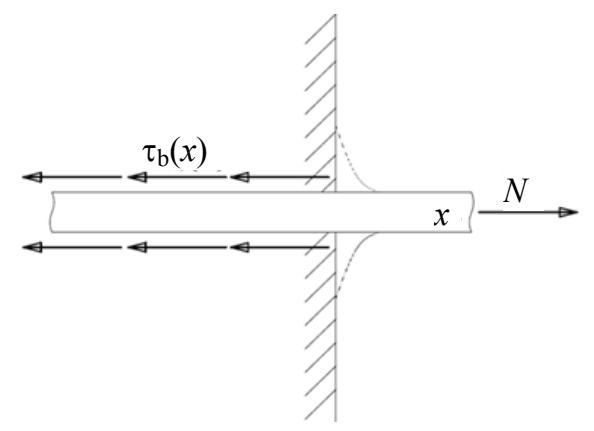

Fig. 3. Pullout testing of samples

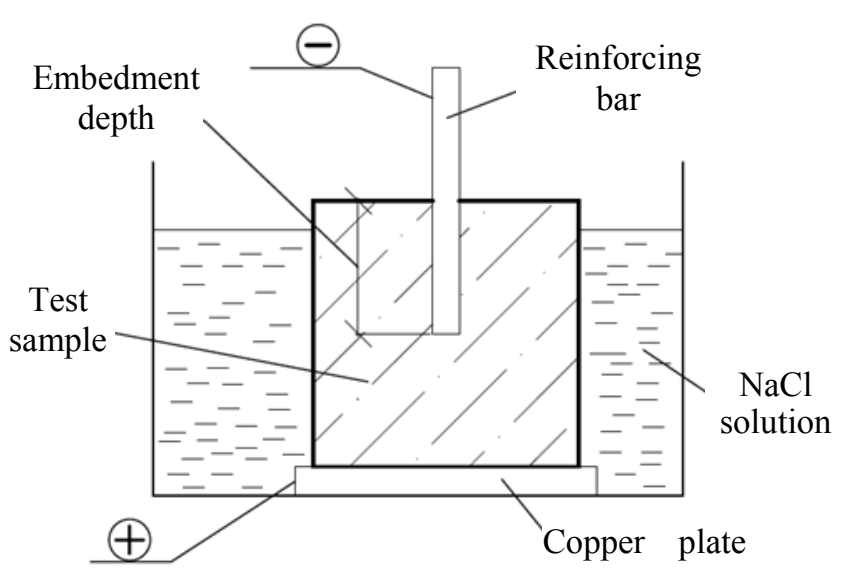

Fig. 4. Schematic representation of the electrochemical system used to induce corrosion of the reinforcing bar

To model the properties of bonding, the database was arbitrarily divided into three parts: training, monitoring and testing. At the same time, $5 \%$ of the experimental data were used for testing, another $5 \%$ for monitoring, and the remaining $90 \%$ for network training. As a result of monitoring, the risk of retraining of the network was reduced. The training database was used to develop a predicting model, while a testing database was used to monitor the repeatability and reliability of the proposed $\mathrm{NN}$ models.

\section{Overview of soft computing methods}

Soft computing is a set of methods that uses tolerances for inaccuracy and uncertainty, and to achieve acceptability, reliability, and low cost in solutions. Fuzzy logic, neurocomputing and probabilistic reasoning are the main components of soft computing. The field of application of soft computing is quite extensive. These technologies are used to solve engineering problems, to perform financial assessments, to conduct medical diagnostics, etc. Methods of soft computing derived from the philosophy of artificial intelligence imitate the human mind.

The most popular methods of soft computing are artificial neural networks.

\section{Neural networks (NN)}

The neural network $(\mathrm{NN})$ is a functional modeling of biological sensory structures of the central nervous system. It can demonstrate a number of characteristics of the human brain, such as the accumulation of experience and the solution of new problems based on the knowledge gained. In neural networks (NNs), there are many cells and connections between inputs and outputs. These connections between the neurons get the 
value of the transfer, which is called the weight. Weights can be updated for each new fragment of information. After implementing the scales, the existing training system is easily updated with data that will be received later. NNs are systems consisting of a set of simple processing elements operating in parallel, whose functions are determined mainly by the connection scheme.

These systems are capable of performing highlevel functions, such as adaptation or training, as well as lower-level functions, such as pre-processing data for various kinds of inputs. For the development of NNs, mathematical theories of teaching, information processing and control, as well as knowledge of the functioning of the biological nervous system, were used.

At the same time, the nnstart tool was used to simulate the neural network, which was also used for soft calculations in MatlabV.R2014a.

If a problem arises, the neural network is used to compare the data of the numeric inputs with the set of numeric data of the outputs. Nftool is used to create and train a network, and evaluate its performance using a root-mean-square error and regression analysis. A twolayer network with direct connection, sigmoid hidden objects and linear solutions that can be satisfied arbitrarily with multidimensional mapping problems, taking into account consistent data and a sufficient number of neurons in its hidden layer. The network was prepared using the Levenberg-Marquardt feedback algorithm. An artificial neuron consists of three main components: weight, displacement and activation function. Each neuron receives inputs $I_{1}, I_{2}, \ldots, I_{n}$, attached by weight $w_{i}$ that indicate the connection power for this input. Each input is then multiplied by the corresponding weight of the neural connection. Evasion can be defined as the type of connection weight with a constant non-zero value added to the summation of weighted inputs (2). A generalized operation of an algebraic matrix is represented in Eq. (3). It is necessary to clearly express mathematical operations in an artificial neuron.

$$
U_{k}=\sum_{j=1}^{n} w_{k} I_{j}+\operatorname{Bias}_{k}
$$

$$
U_{k}=\left[\begin{array}{cccccc}
w_{11} & w_{12} & \cdot & \cdot & \cdot & w_{1 n} \\
w_{21} & w_{22} & \cdot & \cdot & \cdot & w_{2 n} \\
\cdot & \cdot & \cdot & \cdot & \cdot & \cdot \\
\cdot & \cdot & \cdot & \cdot & \cdot & \cdot \\
\cdot & \cdot & \cdot & \cdot & \cdot & \cdot \\
w_{m 1} & w_{m 2} & \cdot & \cdot & \cdot & w_{m n}
\end{array}\right]_{m \times n}\left[\begin{array}{c}
I_{1} \\
I_{2} \\
\cdot \\
\cdot \\
\cdot \\
I_{n}
\end{array}\right]_{n \times 1}+
$$

$$
+\left[\begin{array}{c}
\operatorname{Bias}_{1} \\
\operatorname{Bias}_{2} \\
\cdot \\
\cdot \\
\operatorname{Bias}_{m}
\end{array}\right]_{m \times 1}\left[\begin{array}{c}
U_{1} \\
U_{2} \\
\cdot \\
\cdot \\
U_{m}
\end{array}\right]_{m \times 1}
$$

Since the nftool uses normalized values in the range $[-1,1]$, the input parameters are determined using Equation 3. In addition, the results obtained are also in the normalized form. Equation 4 and the normalization coefficients $a$ and $b$ for the outputs are used in the de-normalization process and to obtain the control.

$$
\beta_{\text {norm }}=a \beta+b,
$$

where $\beta$ is actual input parameter or output values, $\beta_{\text {norm }}$ is the normalized value of the input parameters or outputs in the range from $[-1,1] ; a$ and $b$ are the normalization coefficients given in the following equations (5) and (6). As a result of the normalization process, the smallest numerical value in the array becomes -1 , while the highest value becomes equal to 1 .

$$
\begin{aligned}
& a=\frac{2}{\beta_{\max }-\beta_{\min }} ; \\
& b=\frac{\beta_{\max }+\beta_{\min }}{\beta_{\max }-\beta_{\min }},
\end{aligned}
$$

where $\beta_{\max }, \beta_{\min }$ are maximum and minimum actual values of inputs or outputs, respectively.

The coefficients of normalization of both input and output variables are presented in Table 2 .

In the $\mathrm{NN}$ architecture, at the input level, there are six nodes corresponding to the six prediction factors, eight nodes in the hidden layer and one in the output layer corresponding to the ultimate bond strength $\tau_{\mathrm{b}}$ between reinforcement and concrete. Therefore, to build a NN-based model, the architecture of 6-8-1 NN was obtained (Fig. 5). The NN model used in this study can be simply expressed by Eq. (7). The details of the input and the layers, the activation function (hyperbolic tangent), and the bias are given in equations (7)-(10). It should be emphasized that all numerical variables must be normalized to the range $[-1,1]$ before entering $\mathrm{NN}$. Therefore, it is necessary to enter the normalized values in the mathematical operations specified for the 


\section{Normalization coefficients for the database}

\begin{tabular}{|c|c|c|c|c|c|c|c|}
\hline \multirow{2}{*}{$\begin{array}{c}\text { Normalization } \\
\text { parameters }\end{array}$} & \multicolumn{7}{|c|}{ Input and output variables } \\
\hline & $I_{1}, \mathrm{MPa}$ & $I_{2}, \mathrm{~mm}$ & $I_{3}$ & $I_{4}, \mathrm{~mm}$ & $I_{4}, \mathrm{~mm}$ & $I_{5}, \%$ & $I_{6}, \mathrm{MPa}$ \\
\hline$\beta_{\max }$ & 52.1 & 147.5 & 2 & 25 & 500 & 80 & 31.7 \\
\hline$\beta_{\min }$ & 22.13 & 15 & 1 & 12 & 35.9 & 0 & 1.3 \\
\hline$a$ & 0.066733 & 0.015094 & 2 & 0.153846 & 0.004309 & 0.025 & 0.065789 \\
\hline$b$ & -2.47681 & -1.22642 & -3 & -2.84615 & -1.15471 & -1 & -1.08553 \\
\hline
\end{tabular}

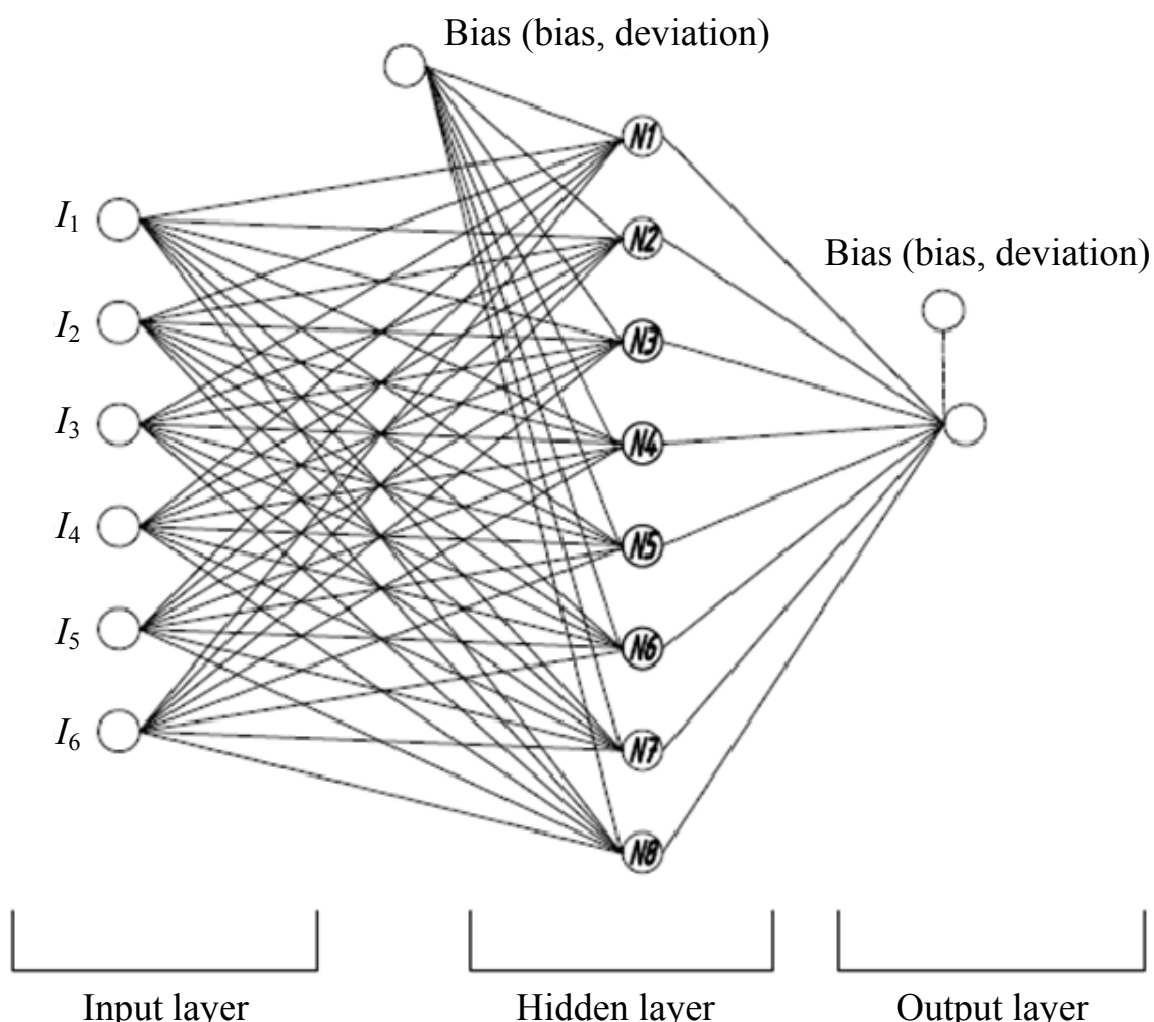

Fig. 5. The NN architecture for the proposed model

NN model. It should also be taken into account that the final result obtained from equation (10) is in the normalized form, which must be de-normalized according to equation (4) and the values of the normalization factors given in Table 2 .

$$
\tau_{\mathrm{b}}=\operatorname{Bias}_{\text {output layer }}+\sum_{j=1}^{n} w_{k} F\left(U_{k}\right),
$$

where Bias $_{\text {output layer }}=-0.72598625301132214$ and $f(x)$ (Hyperbolic tangent) is an activation function.

$$
\begin{gathered}
\tau_{\mathrm{b}}=-0.72598625301132214-0.73052205364589862 \tan h\left(U_{1}\right)+0.43372098218006 \tan h\left(U_{2}\right)- \\
-0.378948852713141 \tan h\left(U_{3}\right)+0.546753081298744 \tan h\left(U_{4}\right)+0.743044141180237 \tan h\left(U_{5}\right)- \\
-0.287177258041315 \tan h\left(U_{6}\right)+0.506892739633613 \tan h\left(U_{7}\right)+0.511933571886970 \tan h\left(U_{8}\right),
\end{gathered}
$$

where $\tau_{\mathrm{b}}$ is ultimate bond strength between reinforcement and concrete, $\mathrm{MPa}, \tan h(x)$ is the activation function (hyperbolic tangent) found by the following equation (9), and $U_{1}, U_{2}, \ldots, U_{8}$ can be calculated from formula (10).

$$
\operatorname{tg} h=\frac{2}{1-\mathrm{e}^{-2 x}}-1
$$




$\left[\begin{array}{ccccccc}-1.867124673755 & -1.970456141181 & -4.648227350451 & 5.676001648574 & 1.327520472019 & -1.755465506282 \\ 0.2503064224871 & -1.260742854080 & 0.8921461740089 & 8.357372886823 & 4.390412668468 & 9.4675705191697 \\ -9.368186441120 & -5.493604583006 & 6.9059256572452 & 3.107102687849 & -5.58700784565 & 23.154702386087 \\ -3.726007098251 & -0.756975200048 & -12.82896288242 & 2.770087904822 & -5.89548833694 & -26.32416136369 \\ 1.7968070762203 & -2.049238735028 & -0.305519465914 & -1.49625722378 & 1.135559385340 & -2.283551791593 \\ 7.1715088540923 & -2.34698114822 & 5.02649043026052 & 0.344211422189 & -5.77532613965 & 4.173420772519 \\ -0.32006490132 & 0.697003679279 & 5.29615191586122 & 4.261154643924 & -5.84236595555 & 17.71885018913 \\ 24.1402334064 & -4.97536745629 & -2.64334234274495 & 4.684149012532 & -0.257163855197 & -25.5886645048\end{array}\right]_{m \times n}$
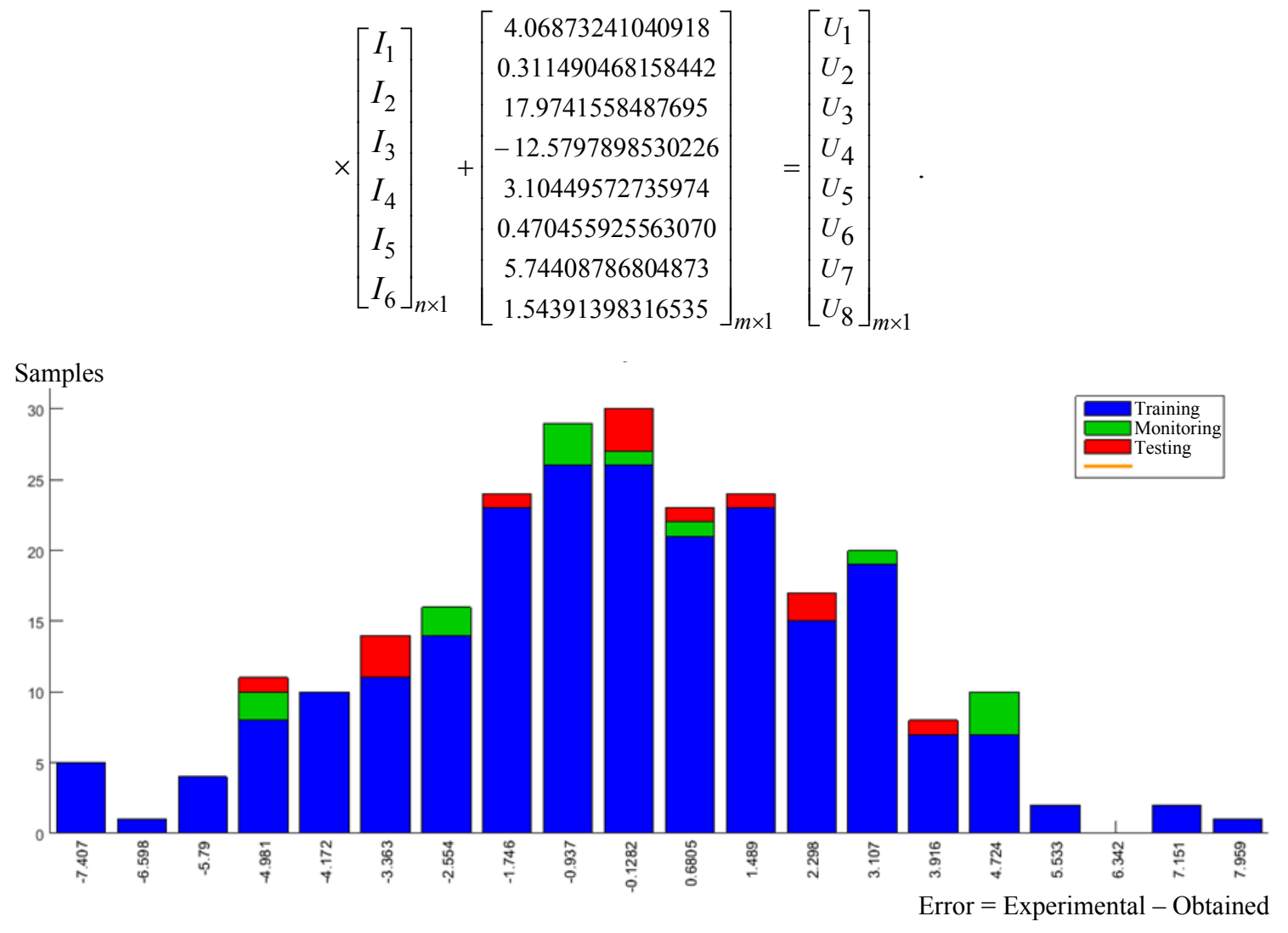

Fig. 6. Error histogram

A comparison of the prediction results obtained with the NN model and the experimental data obtained as a result of the conducted adhesion tests is shown in Fig. 6. To achieve these indicators, it took 83 stages. From Fig. 7 it is obvious that the nature of the learning occurred spasmodically with the gradual accumulation of "knowledge", decreasing the error. Correlation coefficients 0.973 and 0.916 were achieved for the control and test database, respectively. Based on the work done, it can be concluded that the $\mathrm{NN}$ model is reliable (Fig. 8).

\section{Conclusion}

In this paper we presented a study of the ultimate bond strength $\tau_{\mathrm{b}}$ of reinforced concrete elements exposed to various factors. The proposed formulations are based on the most reliable method of soft computing - an artificial neural network (NN). To construct the analytical model, the available experimental data collected by various authors were used. Based on the analysis of the results presented in this study, we can draw the following conclusions.

It is shown that soft computing techniques can be tools to bring empirical evidence ultimate bond strength $\tau_{\mathrm{b}}$ of samples subject to different levels of corrosion. All predicted values were reliable and comparable to those observed. Therefore, the proposed network can be viewed as a useful model with a satisfactory ability to predict.

It is noted that for low levels of experimental values $\tau_{\mathrm{b}}$ up to $4.5 \mathrm{MPa}$ the mean error between the predicted and actual values was the highest for the model compared to other intervals $\tau_{\mathrm{b}}$. 


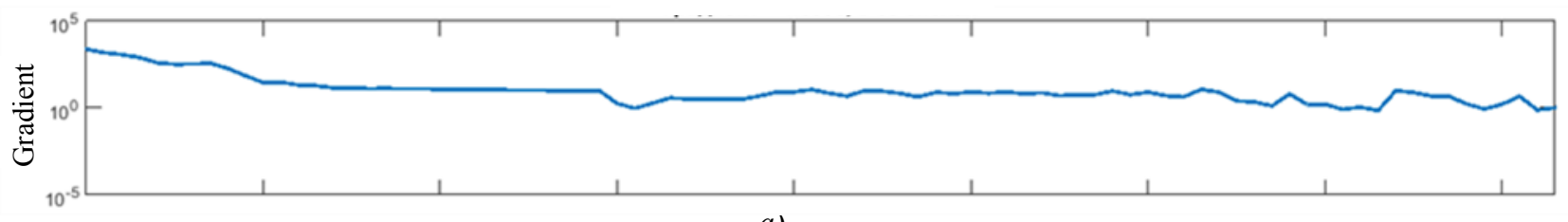

a)

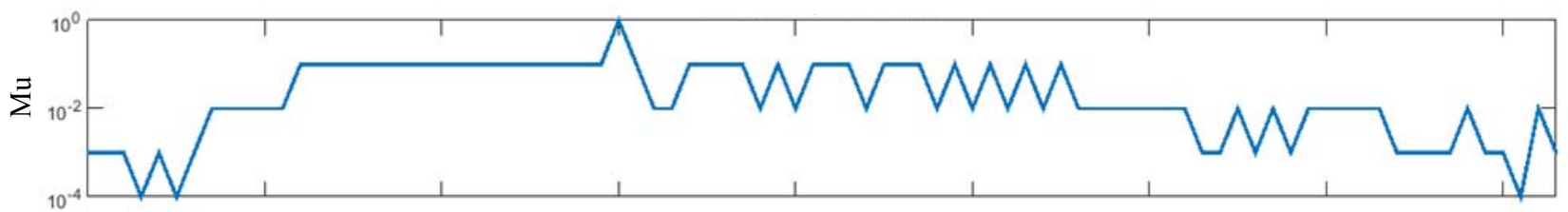

b)

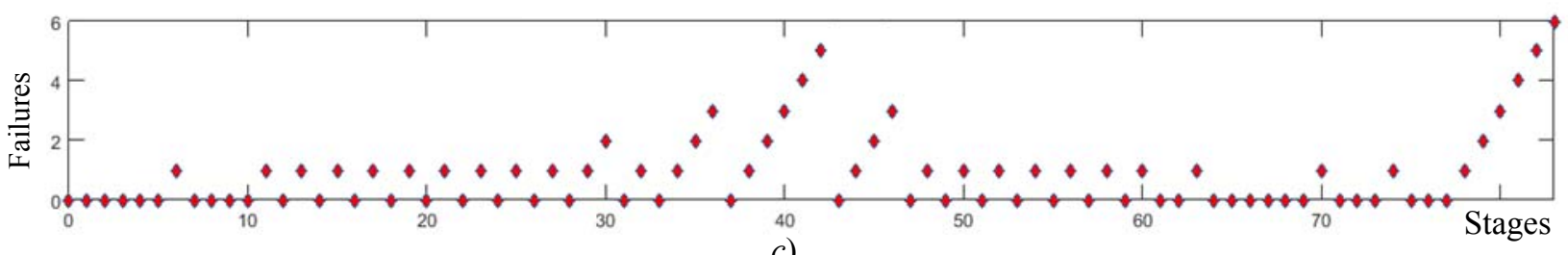

Fig. 7. State of the artificial neural network in the training process for 83 stages:

$a-$ Gradient $=1.0385 ; b-\mathrm{Mu}=0.001 ; c-$ Maximum number of verification $s=6$
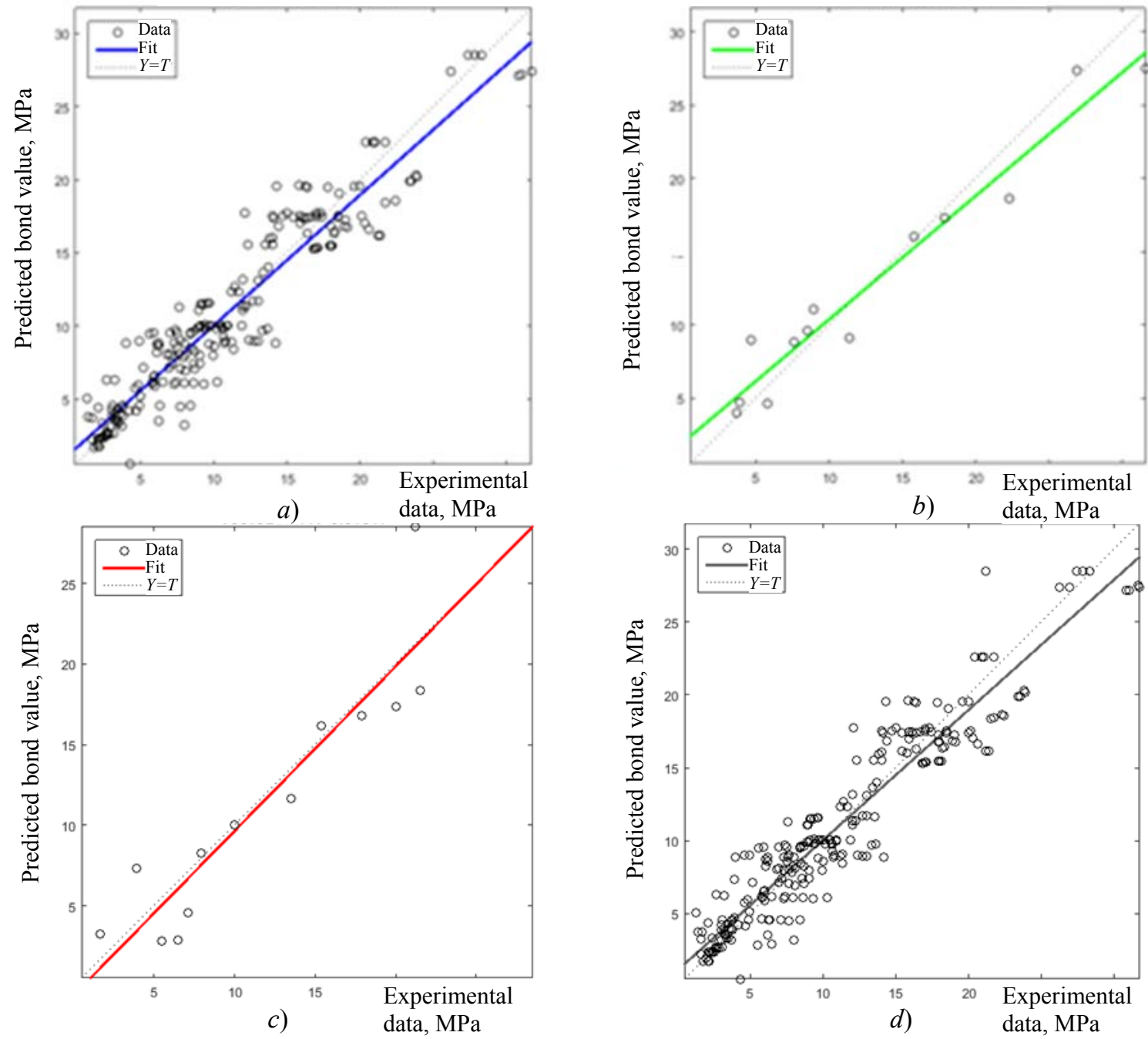

Fig. 8. Model regression analysis:

$a$ - Training: $R=0.94478$, Regression equation $-x=0.89 y+1.1 ; b-$ Monitoring: $R=0.97385$, Regression equation $-x=0.84 y+2.0$; $c$ - Testing: $R=0.91617$, Regression equation $-x=1.0 y-0.56 ; d$ - Model: $R=0.94721$ Regression equation $-x=0.89 y+1.1$ 


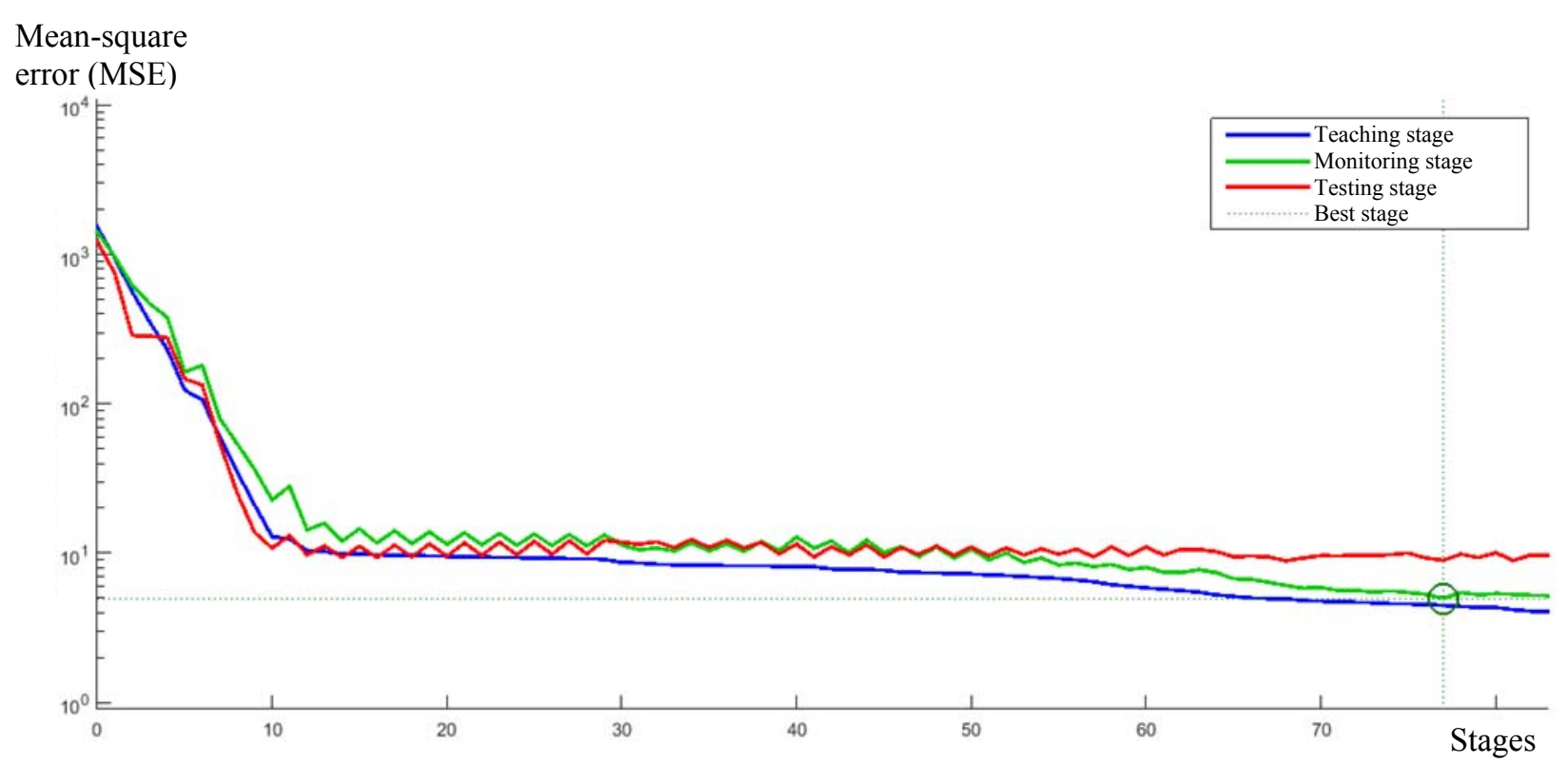

Fig. 9. Results of network training

(The best verification value of 4.9794 occurred at the 77 th stage)

One of the reasons for the deviations may be the inconsistency of the authors in the methodology in testing and making the samples, which were noticeable at high corrosion levels and low strength values of the concrete. According to the observed correlations, the reliability of the proposed model can be considered satisfactory for actual values $\tau_{\mathrm{b}}$ exceeding $4.5 \mathrm{MPa}$.

The correlation coefficient for the training database was 0.947. In addition, to test the databases, correlation coefficients of 0.947 for the first, 0.973 and 0.916 for the latter were achieved (Fig. 8). Despite the fact that the database for testing was not used for training, a high level of prediction was obtained, related to a low mean absolute error percentage and high correlation coefficients. This indicates that the developed model is reliable.

Statistical analysis based on MSE values also showed that the proposed formulations of NN had relatively lower errors (Fig. 9). Observing the general trend in the evaluation of efficiency, it was found that the NN model can be considered as a more preferred prediction model from the existing at the moment.

Since the NN is not capable of making calculations without computer technology, its application for a manual calculation is considered laborious. However, the use of the NN model becomes indispensable when it becomes necessary to predict higher accuracy. At the same time, the use of a computer effectively eliminates the difficulties that arise in computing. The solution is to computerize the NN model with a simple spreadsheet. Thus, this will overcome this insignificant drawback.

\section{References}

1. Amleh L., Ghosh A. Modeling the effect of corrosion on bond strength at the steel-concrete interface with finiteelement analysis. Can J Civ Eng, 2006, vol. 33, pp. 673-682.

2. Berto L., Simioni P., Saetta A. Numerical modeling of bond behaviour in RC structures affected by reinforcement corrosion. Eng Struct, 2008, vol. 30, pp. 1375-1385.

3. Migunov V.N. Ovchinnikov I.I., Ovchinnikov I.G. Eksperimental'no-teoreticheskoe modelirovanie armirovannykh konstruktsij $v$ usloviyakh korrozii [Experimental theoretical modeling of reinforced structures under corrosion conditions]. Penza, PGUAS, 2014. 362 p. (Rus.)

4. Alekseev S.N., Ivanov F.M., Modry S., Shissl' P. Dolgovechnost' zhelezobetona $v$ agressivnykh sredakh [Durability of reinforced concrete in corrosive environments]. Moscow: Strojizdat, 1990, 320 p. (Rus.)

5. Veselov A.A. Raschet dliny zadelki armatury periodicheskogo profilya $\mathrm{v}$ betone [Calculation of the reinforcing length of the periodic profile in concrete]. In Statika i dinamika slozhnykh stroitel'nykh konstruktsij: mezhvuz. sb. tr. [Statics and dynamics of complex building structures: interuniversity. Col.of pap.], Leningrad: LISI, 1980, pp. 148-155. (Rus)

6. Topcu I.B., Boga A.R., Hocaoglu F.O. Modeling corrosion currents of reinforced concrete using ANN. Automat Constr., 2009, vol. 18(2), pp.145-152.

7. Lim C.H., Yoon Y.S., Kim J.H. Genetic algorithm in mix proportioning of high performance concrete. $\mathrm{Cem}$ Concr Res, 2004, vol. 34(3), pp. 409-420.

8. Fairbairn E.M.R., Silvoso M.M., Filho R.D.T., Alves J.L.D. Ebecken NFF Optimization of mass concrete construction using genetic algorithms. Comput Struct, 2004, vol. 82(2-3), pp. 281-299. 
9. Adhikary B.B., Mutsuyoshi H. Prediction of shear strength of steel fiber RC beams using neural networks. Constr Build Mater, 2006, vol. 20(9), pp. 801-811.

10. Duan Z.H., Kou S.C., Poon C.S. Prediction of compressive strength of recycled aggregate concrete using artificial neural networks. Constr Build Mater, 2013, vol. 40, pp. 1200-1206.

11. Ashour A.F., Alvarez L.F., Toropov V.V. Empirical modeling of shear strength RC deep beams by genetic programming. Comput Struct, 2003, vol. 81(5), pp. 331-338.

12. Goh A.T.C. Prediction of ultimate shear strength of deep beams using neural networks. ACI Struct J, 1995, vol. 92(1), pp. 28-32.

13. Sadowski L. Non-destructive investigation of corrosion current density in steel reinforced concrete by artificial neural networks. Arch Civ Mech Eng, 2013, vol. 13(1), pp. 104-111.

14. Sadowski L. Non-destructive evaluation of the pulloff adhesion of concrete floor layers using rbf neural network. J Civ Eng Manag, 2010, vol. 19(4), pp. 550-560.

15. Sakla S.S.S., Ashour A.F. Prediction of tensile capacity of single adhesive anchors using neural networks. Comput Struct, 2005, vol. 83, pp. 1792-1803.

16. Dahou Z., Sbartai Z.M., Castel A., Ghomari F. Artificial neural network model for steel-concrete bond prediction. Eng Struct, 2009, vol. 31(8), pp. 1724-1733.

17. Golafshani E.M., Rahai A., Sebt M.S., Akbarpour H. Prediction of bond strength of spliced steel bars in concrete using artificial neural network and fuzzy logic. Constr Build Mater, 2012, vol. 36, pp. 411-418.

18. Stolyarov Ya.V. Vvedenie v teoriyu zhelezobetona [Introduction to the theory of reinforced concrete], MoscowLeningrad: Strojizdat, 1941, 447 p. (Rus.)

19. Bajkov V.N., Sigalov E.E. Betonnye i zhelezobetonnye konstruktsii: Obshhij kurs [Concrete and reinforced concrete structures: Basic course], Moscow: Strojizdat, 1991, 768 p. (Rus.)

20. Garai T. Issledovanie ankerovki armatury v betone [Investigation of anchoring of reinforcement in concrete]. In Issledovanie prochnosti ehlementov zhelezobetonnykh konstruktsij [Investigation of the strength of reinforced concrete structures]. Sb.tr. NIIZHB, Moscow: Gosstrojizdat, 1959, issue 5, pp. 78-109. (Rus)

21. Kholmyanskij M.M. Kontakt armatury s betonom [Contact of reinforcement with concrete], Moscow: Strojizdat, 1981, 184 p. (Rus.)

22. Kholmyanskij M.M. Raschet tsentral'no armirovannykh prizmaticheskikh ehle-mentov na stseplenie [Calculation of centrally reinforced prismatic elements for bond strength]. In Sb.tr. NIIZHB, Moscow: Gosstrojizdat, 1961, issue 4, pp. 122-153. (Rus.)

23. Kholmyanskij M.M., et al. Stseplenie sterzhnevoj armatury periodicheskogo profilya $\mathrm{s}$ betonom [Bonding of bar reinforcement with a periodic profile of concrete]. In Stseplenie armatury s betonom [Coupling of reinforcement with concrete], Moscow, 1971, pp. 31-37. (Rus.)

24. Kholmyanskij M.M. Zadelka armatury $\mathrm{v}$ betone [Fixing reinforcement in concrete]. Beton $i$ zhelezobeton
[Concrete and Reinforced Concrete], 1965, vol. 11, pp. 21-25. (Rus.)

25. Kol'ner V.M., Aliev SH.A., Gol'dfajn B.S. Stseplenie s betonom i prochnost' zadelki sterzhnevoj armatury periodicheskogo profilya [Concretion with concrete and strength of the insertion of reinforcing bar of the periodic profile]. Beton $i$ zhelezobeton [Concrete and Reinforced Concrete], 1965, vol. 11, pp. 25-27. (Rus.)

26. Kholmyanskij M.M. Tekhnicheskaya teoriya stsepleniya armatury $\mathrm{s}$ betonom $\mathrm{i}$ ee primenenie [The technical theory of reinforcement coupling with concrete and its application]. Beton $i$ zhelezobeton [Concrete and Reinforced Concrete], 1968, vol. 12, pp. 10-18. (Rus.)

27. Kholmyanskij M.M. Metodika ehksperimental'noj issledovaniya stsepleniya armatury $\mathrm{s}$ betonom [Methods of experimental study of reinforcement coupling to concrete]. Metodika laboratornykh issledovanij deformatsij i prochnosti betona, armatury $i$ zhelezobetonnykh konstruktsij [Methods of laboratory studies of deformation and strength of the concrete, rebar and concrete constructions], Moscow, 1962, pp. 138-147. (Rus.)

28. Tevelev Yu.A. Zadelka armatury $\mathrm{v}$ betone pri peremennom stseplenii po dline zony ankerovki [Fixation of reinforcement in concrete with variable bond along the length of the anchoring zone]. Stseplenie armatury s betonom [Coupling of reinforcement with concrete], Moscow, 1971, pp. 14-21. (Rus.)

29. Kholmyanskij M.M. Nadarejshvili G.F., Zajtsev V.V. $\mathrm{O}$ primenenii zakona stsepleniya pri issledovanii mekhanicheskogo vzaimodejstviya armatury periodicheskogo profilya $\mathrm{i}$ betona [On the application of the law of cohesion in the study of the mechanical interaction of reinforcement of a periodic profile and concrete]. Stseplenie armatury $s$ betonom [Coupling of reinforcement with concrete], Chelyabinsk, 1968, pp. 27-29. (Rus.)

30. Kholmyanskij M.M., Kol'ner V.M., Gol'dfajn B.S. Stseplenie s betonom sterzhnevoj armatury periodicheskogo profilya [Coupling of concrete with bar reinforcement of the periodic profile]. Stseplenie armatury s betonom [Coupling of reinforcement with concrete], Chelyabinsk, 1968, pp. 46-47. (Rus.)

31. Tevelev Yu.A. K voprosu rascheta na stseplenie pri peremennom zakone stsepleniya po dline zadelki [To the problem of bond calculating under the variable law of evaluation of the length of the seal]. Stseplenie armatury $s$ betonom [Coupling of reinforcement with concrete], Chelyabinsk, 1968, pp. 34-35. (Rus.)

32. Oatul A.A. Osnovy teorii stsepleniya armatury $\mathrm{s}$ betonom [Basics of the theory of coupling of reinforcement with concrete], Issledovaniya po betonu $i$ zhelezobetonu. Sb.tr. CHPI [Studies on concrete and reinforced concrete. ChPI Col. of papers], Chelyabinsk, 1967, issue 46, pp. 6-26. (Rus.)

33. Oatul A.A. Predlozheniya k postroeniyu teorii stsepleniya armatury $\mathrm{s}$ betonom [Proposals on the construction of the theory of the coupling of reinforcement with concrete], Beton $i$ zhelezobeton [Concrete and Reinforced Concrete], 1968, vol. 12, pp. 8-10. (Rus.) 
34. Tsekhmistrov V.M. Raschet napryazhenij i deformatsij pri vydergivanii armatury iz betonnoj prizmy, opertoj tortsom (obrazets na vydergivanie) [Calculation of stresses and deformations when pulling reinfrocement from a concrete prism supported by an end face (pullout test)], Issledovanie po betonu $i$ zhelezobetonu. Sb. tr. CHPI [Studies on concrete and reinforced concrete. ChPI Col. of papers], Chelyabinsk, 1967, issue 46, pp. 27-43. (Rus.)

35. Oatul A.A., Ivashenko Yu.A. Ehksperimental'noe issledovanie stsepleniya armatury s betonom na rastyanutykh obraztsakh pri kratkovremennom, povtornom i dlitel'nom dejstvii nagruzki [Experimental study of reinforcement of bond to concrete on stretched samples under short-term, repeated and long-term load action], Issledovaniya po betonu $i$ zhelezobetonu. Sb. tr. CHPI [Studies on concrete and reinforced concrete. ChPI Col. of papers], Chelyabinsk, 1967, issue 46, pp. 44-71. (Rus.)

36. Pasepshik V.V. Issledovanie vnutrennego treshhinoobrazovaniya $\mathrm{v}$ tsentral'no armirovannom korotkom rastyanutom obraztse [Investigation of internal cracking in a centrally reinforced short stretched sample], Issledovaniya po betonu i zhelezobetonu. Sb. tr. CHPI [Studies on concrete and reinforced concrete. ChPI Col. of papers], Chelyabinsk, 1967, issue 46, pp. 72-84. (Rus.)

37. Oatul A.A., Kutin Yu.F. Ehksperimental'noe opredelenie differentsirovannogo zakona stsepleniya sterzhnevoj armatury s betonom [Experimental definition of the differentiated law of coupling of core reinforcement with concrete], Issledovaniya po betonu $i$ zhelezobetonu. Sb. tr. CHPI [Studies on concrete and reinforced concrete. ChPI Col. of papers], Chelyabinsk, 1967, issue 46, pp. 72-84. (Rus.)

38. Pasepshik V.V. Primenenie metoda konechnykh ehlementov $\mathrm{v}$ teorii stsepleniya armatury $\mathrm{s}$ betonom [The application of the finite element method in the theory of reinforcement coupling with concrete], Issledovaniya po betonu i zhelezobetonu. Sb. tr. CHPI [Studies on concrete and reinforced concrete. ChPI Col. of papers], Chelyabinsk, 1974, issue 149, pp. 127-132. (Rus.)

39. Tsekhmistrov V.M. Eksperimental'nye issledovaniya zakonov stsepleniya $\mathrm{s}$ betonom sterzhnej [Experimental studies of the bond laws of concrete with bars], Issledovaniya po betonu $i$ zhelezobetonu. Sb. tr. CHPI [Studies on concrete and reinforced concrete. ChPI Col. of papers], Chelyabinsk, 1974, issue 149, pp. 142-148. (Rus.)

40. Oatul A.A., Pyl'neva T.M. Predlozheniya po postroeniyu teorii polzuchesti stsepleniya armatury $\mathrm{S}$ betonom [Proposals on the construction of the theory of creep-coupling of reinforcement with concrete], Zhelezobetonnye konstruktsii [Reinforced concrete structures], Chelyabinsk, 1969. pp. 49-61. (Rus.)

41. Almussallam A.A., Al-Gahtani A.S., Aziz A.A., Rasheeduzzafar Effect of reinforcement corrosion on bond strength. Constr Build Mater, 1996, vol. 10(2), pp. 123-129.

42. Auyeung Y., Balaguru P., Chung L. Bond behavior of corroded reinforcement bars. ACI Mater J. 2000, vol. $97(2)$, pp. 214-220.

43. Shima H. (2002) Local bond stress-slip relationship of corroded steel bars embedded in concrete. In: Proceeding of the third international symposium on bond in concrete, Budapest, Nov 2002 Materials and Structures, pp. 153-158.

44. Zhao Y., Jin W. Test study on bond behavior of corroded steel bars and concrete. $J$ Zhejiang Univ (Engineering Science Edition), 2002, vol. 36(4), pp. 352-356 (in Chinese)

45. Fang C., Lundgren K., Chen L., Zhu C. Corrosion influence on bond in reinforced concrete. Cem Concr Res. 2004, vol. 34(11), pp. 2159-2167.

46. Horrigmoe G., Sæther I., Antonsen R., Arntsen B. Laboratory investigations of steel bar corrosion in concrete. Background document SB3.10. Sustainable bridges: assessment for future traffic demands and longer lives. A project co-funded by the European Commission within the Sixth Framework Programme, 2007

47. Chung L., Kim Jh.J, Yi S.T. Bond strength prediction for reinforced concrete members with highly corroded reinforcing bars. Cem Concr Compos. 2008, vol. 30(7), pp. 603-611.

48. Yalciner H., Eren O., Serhan S. An experimental study on the bond strength between reinforcement bars and concrete as a function of concrete cover, strength and corrosion level. Cem Concr Res. 2012, vol. 42(5), pp. 643-655.

49. Migunov V.N. Ovchinnikov I.G. Dlitel'nye ehksperimental'nye issledovaniya vliyaniya prodol'nykh treshhin $\mathrm{v}$ zashhitnom sloe betona na izmenenie dolgovechnosti, kratkovremennoj zhyostkosti i prochnosti vnetsentrenno szhatykh $\mathrm{s}$ malym ehkstsentrisitetom stroitel'nykh obychnykh zhelezobetonnykh ehlementov [Long-term experimental studies of the effect of longitudinal cracks in the protective layer of concrete on the change in durability, short-term stiffness and strength of eccentricity of eccentric construction of ordinary conventional reinforced concrete elements]. Izv. vuzov. Stroitel'stvo [University Bulletin. Civil Engineering]. 2010, issue 2, pp. 125-130. (Rus.) 